\title{
Rotifera (Monogononta) diversity in subtropical waters of Argentina
}

\author{
S. Jose de Paggi 1
}

Keywords : Rotifera, Neotropical region, shallow lakes, littoral area, acid waters, new records, new species.

The rotifer fauna of twenty five localities (mainly shallow lakes) from Corrientes, Argentina was studied. 136 taxa were identified, 20 of which, from the genera Lecane, Lepadella, Ploesoma, Ptygura, Squatinella, Testudinella and Trichocerca are new to the Argentine fauna. Most of these are (sub)tropical in distribution, and $8 \%$ are endemic to South America. Ploesoma africana Wulfert, Ptygura kostei n.sp., Testudinella brevicaudata Yamamoto and Trichocerca vernalis Hauer are recorded from the Neotropical region for the first time. The rotiferan species richness of this area, is remarkable. The highest diversity was recorded from vegetated lakes, with acid waters, where one locality yielded 56 species.

\section{Diversité des Rotifères (Monogononta) dans les eaux subtropicales d’Argentine}

Mots clés : Rotifères, Neotropis, lacs peu profonds, zone littorale, eaux acides, nouvelles récoltes, espèce nouvelle.

La faune des Rotifères de 25 lacs peu profonds de la région de Corrientes (Argentine) a été étudiée. 136 taxa ont été recensés dont 20 nouveaux pour la faune d'Argentina : ils appartiennent aux genres Lecane, Lepadella, Ploesoma, Ptygura, Squatinella, Testudinella et Trichocerca. La majorité a une distribution subtropicale, cosmopolite et $8 \%$ sont endemiques d' Amérique du Sud. Ploesoma africana Wulfert, Ptygura kostei n.sp., Testudinella brevicaudata Yamamoto et Trichocerca vernalis Hauer sont citées par la première fois dans la région néotropicale. C'est dans les lacs acides avec végétation littorale qu'on a observé la plus grande diversité : 56 espèces ont été dénombrées dans une seule station.

\section{Introduction}

The rotifer fauna of Argentina is partially documented. Nearly 300 species have been recorded from this country which is as large as $4.025 .696 \mathrm{~km}^{2}$ (Jose de Paggi 1990). Argentina extendes over a large latitudinal range (from $22^{\circ}$ to $56^{\circ} \mathrm{S}$ ) besides with large altitudinal variations. Consequently there exists a great diversity of climates and environments, so one can expect a very high diversity of rotifers. Biogegraphically the Argentine territory is included into two large subregions: Guyana-Brazilian and Andean-Patagonian. Up to now, the largest number of rotifers has been recorded from the Guyana-Brazilian area which is rich in

1. Instituto Nacional de Limnologia (CONICET) Macia 1933, 3016 Santo José, Santa Fe, Argentina. lentic waters and floodplain rivers. Nevertheless there are many unexplored areas in this subregion and most investigations were based on pelagic samples only. The vegetated littoral zones have been relatively little studied, so few representatives of littoral genera appear in the rotifer list from Argentina.

In the present paper the rotifer fauna of a hitherto unknown area of Guyana-Brazilian subregion is analyzed.

\section{Study site and methods}

The area is located in the northeast of Argentina, Corrientes province, in a subtropical band between $28^{\circ}$ and $30.5^{\circ} \mathrm{S}$, near the Paraná river. It is very rich in wetlands, rivers, streams and shallow lakes $(<5 \mathrm{~m})$ mainly formed by eolic action during a dry period in the Holocene (Iriondo 1981). These lakes have sandy bottoms and transparent waters, most of them are densely vegetated. 
Fifty eight samples were collected during late spring (4 to 10 December 1992) in 25 water bodies, including shallow lakes («lagunas»), pools and rivers (Table 1). The number of samples by locality were in relation to the size of water bodies (see Table 1). These were taken in open waters and among the littoral vegetation. In the rivers, samples were also taken in lateral swamps. Samples were collected with a $50 \mu \mathrm{m}$ mesh cone net and preserved in the field in $4 \%$ formalin. The sampling method was qualitative. The physical and chemical parameters were measured directly in the field : transparency (Secchi disk), temperature (mercury thermometer), $\mathrm{pH}$ (Hellige comparator), conductivity (conductivity meters) and oxygen content (oxygen meters) (Table 1).

\section{Results}

The area under consideration comprises three geographical groups of water bodies (Fig. 1): Group I with $\mathrm{pH}$ values ranging from 6 to 8.6, without vegetation or with Potamogeton, Cabomba, Ludwigia ; group II water bodies with pH 5.8 to 6.1, with a dense macro- phyte growth, mainly consisting of Myriophyllum, Egeria, Hydrocotyle, Nymphoides, Azolla and Salvinia; group III pH 7.2 to 8.4 without vegetation, except the localities 18 (with Potamogeton) 21 (Azolla, Salvinia, Pistia), and 22 (covered by Elodea). The water temperature ranged from $25^{\circ}$ to $34^{\circ} \mathrm{C}$. Group I and II are in a lowland wetland area, group III is on higher elevation.

136 taxa, belonging to 37 genera were identified from 25 water bodies, however the total is incomplete because some unidentifiable taxa were found, twenty species are new records for Argentina and four species are new to the Neotropical region.

The total number of rotifer species traced in the samples at each site varied from 2 (Laguna Mula) to 56 (Laguna El pacu).

\subsection{New records and selected species: taxonomic comments and distribution in the Neotropical region}

Twenty species of the genera Lecane, Lepadella, Ptygura, Ploesoma, Squatinella, Testudinella, Trichocerca, were recorded for the first time from Argentina (Table 2).

Table 1. List of localities and values of temperature $\left({ }^{\circ} \mathrm{C}\right)$, transparency $(\mathrm{m}), \mathrm{pH}$, conductivity $(\mu \mathrm{S} / \mathrm{cm})$, samples and species numbers, respectively (* vegetated water bodies).

Tableau 1. Liste des localités, température $\left({ }^{\circ} \mathrm{C}\right)$, transparence $(\mathrm{m}), \mathrm{pH}$, conductivité $(\mu \mathrm{S} / \mathrm{cm})$, nombre d'échantillons et nombre d'espèces (* localités avec végétation).

\begin{tabular}{lcccccc}
\hline & Temp. & Secchi. & pH & Cond. & $\begin{array}{c}\text { NR. } \\
\text { Samples }\end{array}$ & $\begin{array}{c}\text { NR. } \\
\text { Species }\end{array}$ \\
& & & & & 3 & 29 \\
1 Santa Lucía River* & 25.0 & & 6.0 & 99 & 3 & 17 \\
2 Laguna* Caraguatay & 25.0 & 0.06 & 6.0 & 385 & 2 & 3 \\
3 L. El Varillar & 26.0 & 0.06 & 6.1 & 397 & 2 & 15 \\
4 L. La Cruz & 25.0 & 1.22 & 6.0 & 122 & 2 & 20 \\
5 L. Soto* & 27.5 & 0.45 & 8.6 & 153 & 4 & 9 \\
6 L. Pago de los deseos* & 29.8 & 1.20 & 7.4 & 52.5 & 3 & 22 \\
7 L. Duna* & 30.0 & 0.82 & 7.8 & 87.4 & 3 & 2 \\
8 L. Mula & 30.0 & 0.52 & 8.4 & 157 & 1 & 21 \\
9 Sarandí Stream* & 30.0 & 0.10 & 6.0 & 1013 & 4 & 10 \\
10 L. Pistia & 30.0 & 0.60 & 6.0 & 1846 & 2 & 51 \\
11 L. Junco* & 29.0 & 0.64 & 6.1 & 34 & 4 & 56 \\
12 L. El Pacú* & 29.5 & 0.50 & 6.0 & 93 & 3 & 40 \\
13 L. Concepción & 25.0 & 0.69 & 5.8 & 32 & 2 & 25 \\
14 L. Timbocito* & 30.0 & - & - & 25 & 2 & 1 \\
15 Farm Pond & 27.2 & 0.16 & 7.4 & 41 & 1 & 1 \\
16 Avalos Stream & 29.5 & 0.80 & 8.4 & 417 & 1 & 14 \\
17 Stream near Mercedes & 27.2 & - & 7.8 & 387 & 1 & .12 \\
18 Farm Pond La Cantera* & 28.0 & - & 7.2 & 111 & 2 & 20 \\
19 Stream in C. Cuatiá & 23.5 & - & 7.2 & 103 & 1 & 3 \\
20 Laguna La Cantera & 27.0 & - & 7.8 & 61.3 & 1 & 7 \\
21 Swamp (Mocoretá)* & 26.0 & 1.55 & 7.4 & 550 & 2 & 37 \\
22 Farm Pond in Sauce* & 26.0 & - & 7.9 & 242 & 2 & 22 \\
23 Guayquiraró River & 27.0 & - & 7.2 & 166 & 1 & 14 \\
24 Farm Pond in Sauce & 28.5 & - & 7.4 & 84 & 1 & 7 \\
25 Feliciano River & 28.5 & - & 7.8 & 1250 & 1 & 14 \\
\hline
\end{tabular}




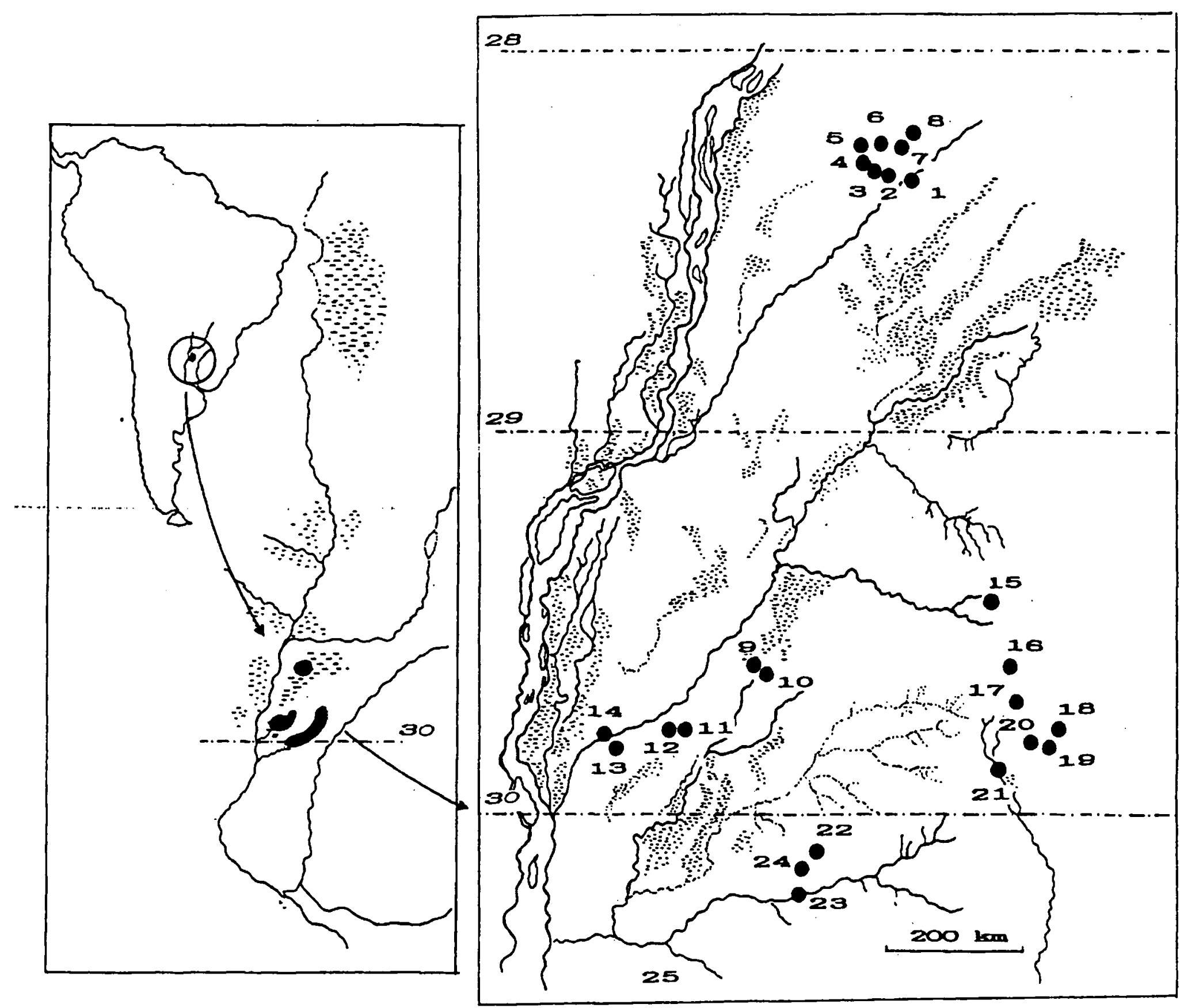

Fig. 1. Geographical localization of the study area and sampling sites (group I : 1-8, group II : 9-14, group III : 15-25). Fig. 1. Localisation géographique de la zone d'étude et sites de récolte des rotifères (groupe I : 1-8, II : 9-14, III : 15-25).

Some of the recorded taxa are cosmopolitan as Lepadella cristata (Rousselett, 1893) (Figs. 2 a,b), widely distributed in Neotropical region, principally in acid waters ( Koste 1972a,1986, Koste \& Robertson 1990, Koste \& Böttger 1992, Schmid Araya 1991), Testudinella incisa (Ternetz, 1892) (Fig. 3) and Testudinella parva (Ternetz, 1892) (Fig. 4) both recorded previously from Neotropis (Koste \& Jose de Paggi 1982). The following species are interesting:

*Lecane amazonica (Murray, 1913) (Fig. 5) (syn. L. murrayi Hauer, 1965, after Segers 1993)
According to Koste (1972a) and Koste \& Böttger (1992) this species prefers acid or slightly acid waters and warm temperatures. In this study it was found in Laguna Junco (pH 6.1, $29^{\circ} \mathrm{C}$ ). Up-to-now Lamazoni$c a$ was recorded only from South America: Brazil and Ecuador (Thomasson 1971, Koste \& Robertson 1990, Koste \& Böttger 1992).

*Lecane braziliensis Segers, 1993 (Fig. 6)

This is the first record of the species outside Brazil. It was described from Roraima, Brazil (Segers et al. 1993a). In Argentina it has been previously found in a 
Table 2. List of rotifer taxa. Numbers refer to the localities (Table 1) (* new record stet to Argentina, ** new record to the Neotropical Region). Tableau 2. Liste des espèces récoltées. Les nombres correspondent aux localités du tableau 1 (* espèces nouvelles pour l'Argentine, ** espèces nouvelles pour la région néotropicale).

Anuraeopis fissa (Gosse), 12-14

A. navicula Rousselet, 12, 14, 20, 22, 23

Ascomorpha ecaudis (Perty), 9, 23

Asplanchna intermedia (Hudson), 2, 14, 25

Brachionus angularis Gosse, 13, 14, 16, 25

$B$. bidentatus Anderson, 2, 9, 11, 12, 15

B. caudatus Barrois \& Daday, 12, 17

B. c. Barrois \& Daday f. austrogenitus Ahlstrom, 12, 14, 23

B. c. Barrois \& Daday, f. personatus Ahlstrom, 12, 21, 23, 25

B. chelonis Ahlstrom, 14

B. dolabratus Harring, 14, 20

B. falcatus Zacharias, 7, 15

B. havanaensis Rousselet, 5, 11, 12

B. quadridentatus (Hermann), 2, 11-13, 17, 21, 23, 25

B. zahniseri Ahlstrom, 1

Cephalodella catellina (O.F.Muller), 11, 15

B. mucronata Myers, 13

Collotheca cf coronatta (Cubitt), 9, 11, 13

Colurella uncinata (O.F.Muller), 5, 12, 14

Conochilus coenobasis Skorikov, 6, 11-13, 20, 25

C. unicornis Rousselet, 12, 13

Dicranophorus cf. hauerianus Wiszniewski, 12, 13

Dipleuchlanis propatula (Gosse), 21

Epiphanes clavulata (Ehrenberg), 22

Euchlanis dilatata (Ehrenberg), 11-13, 16

E. incisa Carlin, 1, 2, 7, 11, 12 .

Filinia longiseta (Ehremberg), 9, 14, 16, 17, 20

F. opoliensis (Zacharias), 3, 8, 15, 16, 21, 24

F. terminalis (Plate), 11-14, 23

F. pejleri Hutchinson, 25

Hexarthra intermedia braziliensis (Hauer), 3, 5, 15, 17, 25

H. mira (Hudson), 24

Horaella thomassoni Koste, 11, 12

Keratella americana Carlin, 5, 12

K. cochlearis (Gosse), 1, 5, 7, 9, 11-13, 15, 17, 23-25

$K$. lenzi (Hauer), 9, 11-14, 21, 23, 24

K. tecta (Gosse), 5, 6, 9, 11, 12

K. tropica (Apstein), 9, 13, 17, 21, 25

Lecane aculeata (Jakubski), 2, 5, 10, 21

* L. amazonica (Murray), 18

* L. braziliensis Segers, 6

L. bulla (Gosse), 1, 2, 5, 6, 7, 10-16, 18, 19, 21-23

L. closterocerca (Schmarda), 4, 9, 10-12, 18, 21-23

L. cornuta (Muller), 1, 4, 7, 13, 14, 18, 21-23

L. crepida Harring, 7, 12, 13, 18

L. crepida Harring f. longidactyla (Koste), 14, 16, 22

L. curvicornis (Murray), 4, 5, 7, 22

L. decipiens (Daday), 1, 11, 12, 18

L. doryssa (Harring), 4

L. elsa Hauer, 4, 7, 11, 24

L. elegans Harring, 13

L. flexilis Harring, 5, 11

L. furcata (Murray), 1, 7

L. halyclista Harring \& Myers, 1, 12, 21
L. hamata (Stokes), 1, 4, 5, 9, 11-14, 18, 21, 23

L. hastata (Murray), 18

L. hornemanni (Ehrenberg), 5, 7, 11, 13, 15, 18, 22

L. leontina (Turner), 1, 4, 7, 9, 11, 12, 21-23

L. ludwigii (Eckstein), 6, 13, 21

* L. ludwigii (Eckstein) f. marshi Harring, 11

L. ludwigii (Eckstein) f. ohioensis (Herrick), 5, 9, 11, 12, 23

L. luna O.F.Muller, 2, 4, 5

L. lunaris (Ehrenberg), 1, 3, 4, 7, 11-14, 22

* L. marchantaria Koste \& Robertson, 5

L. monostyla (Daday), 4, 11-13

L. nana (Murray), 2

L. obtusa (Murray), 5, 21-23

L. papuana (Murray), 11, 14, 22, 23

L. proiecta Hauer, 11

L. pyriformis (Daday), 2, 5, 11, 12, 13, 16, 21, 23

L. quadridentata (Ehrenberg), 2, 11, 12

L. rhytida Harring \& Myers, 12, 21

L. scutata (Harring \& Myers), 11-13

L. signifera (Jennings) f. ploenensis (Voigt), 4, 11, 13

L. stenroosi (Meissner), 21

L. stichaea Harring, 4

L. tenuiseta Harring, 21

L. ungulata (Gosse), 1, 7, 12, 21, 22

Lepadella acuminata (Ehrenberg), 25

* L. biloba (Hauer), 1, 21

L. costata Wulfert, 11

* L. cristata (Rousselet), 22

* L. donneri Koste, 1,7

* L. ehrenbergi (Perty), 7

* L. elongata Koste, 13, 14

L. ovalis (O.F.Muller), 1, 2, 13, 18, 23

L. patella (O.F.Muller), 1, 2, 5, 11-13, 14, 23

L. rhomboides (Gosse), 2, 10, 12, 13

Lophocharis salpina (Ehrenberg), 1, 21

Macrochaetus longipes Myers, 9, 10, 13 $M$. sericus (Thorpe), 2, 6, 11, 12, 16, 21

Monommata longiseta (O.F.M.), 9, 11

Mytilina bisulcata (Lucks), 1, 12, 22

M. mucronata (O.F.Muller), 23

$M$. ventralis (Ehrenberg), 5, 7, 9, 11, 12, 16

Notommata copeus Ehrenberg, 12

Plationus patulus (O.F.Muller), 4, 7, 10-12, 16, 18, 21-23, 25

Platyias quadricornis (Ehrenberg), 1, 21

P. leloupi (Gillard), 11

** Ploesoma africana Wulfert, 11

Pompholix complanata Gosse, 9, 12, 15, 17

Polyarthra dolichoptera Idelson, 17, 19, 22, 25

$P$. vulgaris Carlin, 1, 6, 9, 11-17, 21, 23, 24

** Ptygura kostei n. sp., 21

P. libera Myers, 11

Scaridium longicaudum (O.F.Muller), 1, 9, 14

* Squatinella bifurca (Bolton), 13, 21

* S. leydigi Zacharias, 1

* S. lamellaris (Muller), 12 
Table 1. Continued.

Tableau 1. Suite.

Testudinella ahlstromi Hauer, 9, 10, 11, 18, 21

** T. brevicaudata Yamamoto, 6

* T. incisa (Ternetz), 1, 7

T. mucronata (Gosse), 12, 21, 22, 23

* $T$. ohlei Koste, $1,11,12$

* T. parva (Ternetz), 4, 11, 21

T. patina (Hermann), 1, 6, 7, 9, 10-13, 16-18, 22, 23, 25

T. patina (Hermann) f. intermedia Anderson, 22

T. tridentata Smirnov, 22

Trichocerca bicristata (Gosse), 2, 7, 9, 11, 12, 14, 22

T. brachyura (Gosse), 13

T. braziliensis (Murray), I

T. cylindrica (Imhof), 12

T. elongata (Gosse), 11
* T. hollaerti De Smet, 18

T. insignis (Herrick), 11, 13, 14

T. longiseta (Schrank), 12

T. porcellus (Gosse), 12, 22

T. pusilla (Lauterborn), 12

T. rattus (O.F. Muller), 5

T. similis (Wierzejski), 1, 12, 23

T. stylata (Gosse), 13

T. tigris (O.F. Muller), 12

** T. vernalis (Hauer), 2

Trichotria tetractis (Ehrenberg), 1, 11, 12, 18

Tripleuchlanis plicata Levander, 16, 21

Wolga spinifera (Western), 11, 17, 2 rice field in Corrientes near the region now studied (Martinez \& José de Paggi, unpubl.) here it is recorded from Pago de los deseos Lake. Lecane braziliensis was found in waters with low conductivity $(72 \mu \mathrm{S} / \mathrm{cm}$ in the rice field and $52.5 \mu \mathrm{S} / \mathrm{cm}$ in Pago de los deseos).

* Lecane decipiens (Murray, 1913) (Fig. 7)

This is a relatively common species in South and Central America (Segers 1995), however it is the second record in Argentina (Modenutti \& Claps 1988, not illustrated). Many records of this taxon are misidentified as L. hamata (Segers 1996) but L.decipiens can ready be distinguished because it has the head margin coincident and convex, and the dorsal plate ending in a small transverse fold. Few individuals were found in three localities.

* Lecane hornemanni (Ehrenberg, 1834)

(Figs. 8 a-c)

So far, the single Argentine record of this species was from Lake Hess, eastern Patagonia (Thomasson 1963). However, the presence of this common tropical and subtropical species in an Andean lake should be confirmed. This species was frequently found during this study. Recently, Segers (1995) synonymized L. nodosa Hauer, 1938 with L. hornemanni. This author stated that there are no significant differences between them, because the knobby hemispheres surface of the lorica of L.nodosa could be a fixation artefact. In this study the both forms were found: typic form with smooth lorica (Fig. 8a) in three localities (Duna, Soto, Tajamar; pH: 7.4 to 8.6 ) and individuals with knobby hemispheres, smallest, (Figs. 8b-c) in two localities (La Cruz, Junco, pH 6.00 to 6.10). The later form was recorded from Brazil as $L$. nodosa, in waters with $\mathrm{pH}$ 5.2-6.0 (Brandorf et al. 1982) and from Australia, in water with pH 6.3 (Koste \& Shiel 1990). This difference in ecological conditions of the habitat, is noticeable.

L. hornemanni has been recorded from Brazil, Venezuela, Panama, Antilles (Koste \& José de Paggi, 1982).

* Lecane ludwigii (Eckstein, 1883) f. marshi Harring, 1914 (Fig. 9)

Segers (1995) synonymized L. ohioensis with L. ludwigii on the basis of the great variability in the shape of the posterior projection of the foot plate. In the group of synonymized taxa, $L$. ludwigii f. marshi shows an unusual and different variant in the frontal spines (long, slender and curved as a hook), but the other features agree with $L$. ludwigii.

L.ludwigii f. marshi (only three individuals) and $L$. ludwigii f .ohioensis (Fig. 10) were both found coexisting in Laguna Junco without intermediate forms. Besides of the difference in shape, they differ in the size, f.ohioensis is smaller than f.marshi (lorica length 105 and $130 \mu \mathrm{m}$, respectively). A more profound taxonomic analysis, principally at the population level, appears necessary to determine the status of this species and its morphological variants.

L. ludwigii f. marshi is not common, it was originally described from Panama canal zone and later found in China too (Harring \& Myers 1926).

* Lecane marchantaria Koste \& Robertson, 1983 (Fig. 11)

The species is characterized by the egg shaped lori$\mathrm{ca}$, with the ventral anterior margin more deeply concave than the dorsal margin. Only known from South America: Brazil and Peru (Koste \& Robertson 1983, Koste 1988). In this study it was found in Laguna Soto (pH 8.6). 

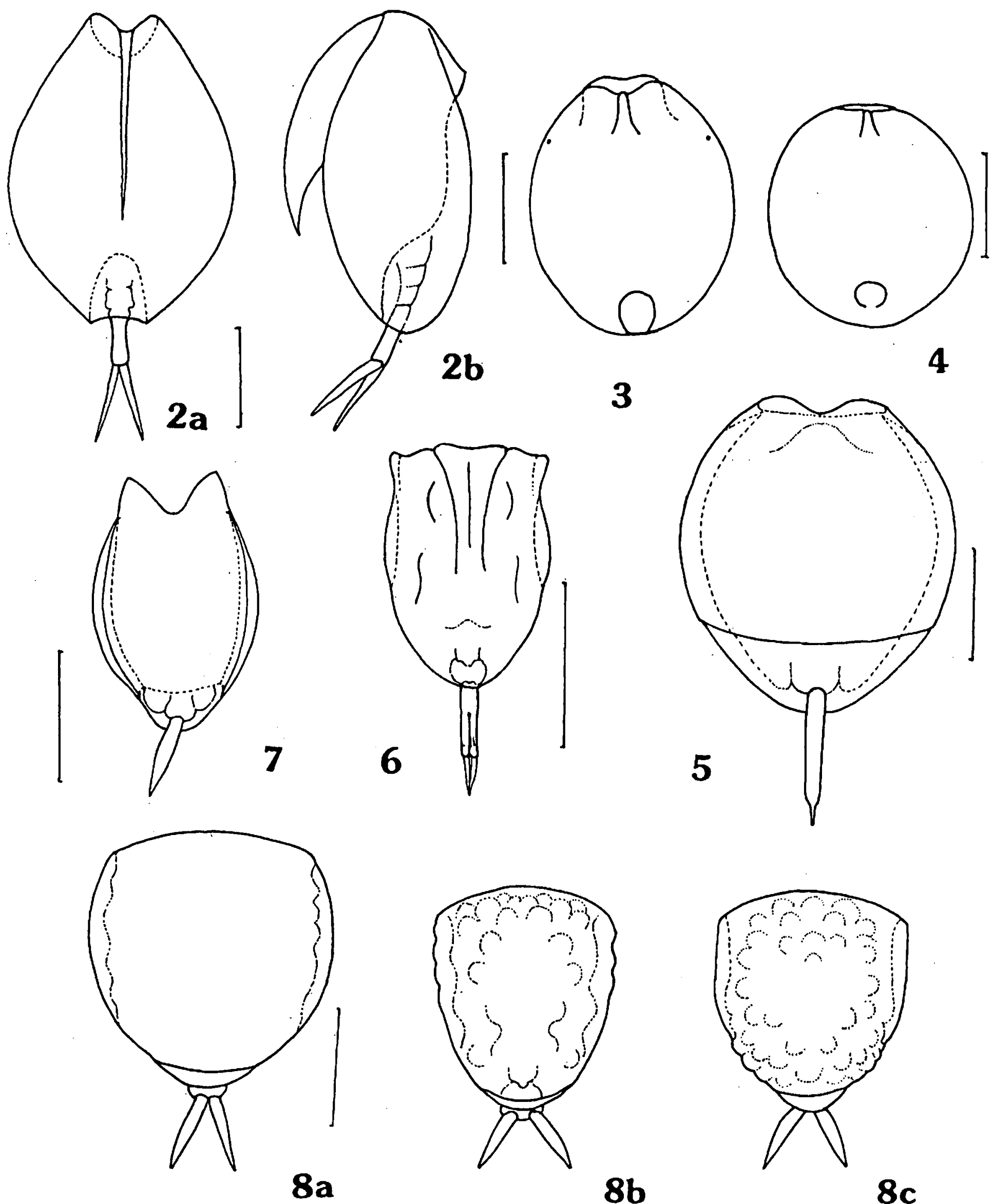

$8 b$

8c

Figs. 2-8. 2 a-b. Lepadella cristata; a: dorsal; b: Jateral. 3. Testudinella incisa, ventral. 4. T. parva, ventral. 5. Lecane amazonica, ventral view. 6. L. braziliensis, dorsal. 7. L. decipiens, ventral. 8. a-c. L. hornemanni, dorsal; (a: Laguna Soto; b: L. La Cruz; c: L. Junco). Scales $50 \mu \mathrm{m}$.

Figs. 2-8. 2 a-b. Lepadella cristata; a: vue dorsale, b: vue latérale. 3. Testudinella incisa, vue ventrale. 4. T. parva, vue ventrale. 5. Lecane amazonica, vue ventrale. 6 . L. braziliensis, vue dorsale. 7 . L. decipiens, vue ventrale. 8 a-c. $L$. hornemanni, vue dorsale; (a : Laguna Soto; b: La Cruz; c: L. Junco). Echelles : $50 \mu \mathrm{m}$. 
* Lepadella biloba Hauer, 1958 (Fig. 12)

This species was alternatively considered as a form, later a subspecies of L.patella Hauer and recently Segers \& De Meester (1994) elevated the taxon to full species rank. It was previously found in Bolivia (Segers et al. 1994).

\section{*Lepadella donneri Koste, 1972 (Fig. 13)}

This species, known only from the Neotropis, is easly distinguished by the lateral sulci in the anterior half of the lorica. It was recorded from Brazil, Peru and Ecuador (Koste 1972a,1988, Koste \& Böttger 1992).

* Lepadella ehrenbergi (Perty, 1850) (Fig. 14)

It resembles L. bicornis Vassist \& Battish, 1971, but the latter species is characterized by its equal toes. In the Neotropical region $L$. ehrenbergi was pointed out in species lists from Venezuela and Brazil (Hauer 1956, Brandorff et al. 1982). The only illustrated records correspond in fact to L. bicornis (Koste 1974b).

* L. elongata Koste, 1992 (Fig. 15)

(syn.: L. quadricarinata f. procera Klement, 1959, L.acuminata after Koste, 1972)

On the basis of the absence of four ribs over the foot opening and lorica outline, Koste (in Koste \& Böttger 1992) described it as a new species. L. elongata has an elongated lorica outline, narrow posterior region and deep pedal notch. In South America, recorded from Brazil and Ecuador (Koste \& Böttger 1992, Segers \& Dumont 1995). L. elongata was found in acid waters (pH 5.8, Laguna Concepción).

\section{* Squatinella bifurca (Bolton, 1884) (Fig. 16)}

Body cylindrical, with two spines in median line of posterior lorica. The species was found between submerged macrophytes, in the littoral of Laguna Concepción. Though cosmopolitan, S. bifurca was recorded previously only from Amazonas, Corumba River (Koste 1972a).

* Squatinella lamellaris (Muller, 1786) f. mutica (Ehrenberg, 1838) (Figs. 17 a,b) (syn.: S. mutica Ehrenberg 1832, after Segers et al. 1991)

Caudal margin of the lorica semicircular, foot with three pseudo segments, without spine on the last foot pseudo-segment. In acid waters, widespread in distribution and common in Neotropis too, recorded as $S$. mutica from Amazonas', Ecuador, Jamaika (Koste 1974a, Koste \& Böttger 1992, Koste et al. 1993).

Squatinella leydigi Zacharias, 1886 (Figs. 18 a,b)

Body oval, the dorsal lorica has ribs similar to those described by Pejler (1962) and a long spine. Foot with two pseudo-segments.
S. leydigi is an inhabitant of acid waters (Koste 1978). Few individuals were found in a sample from the banks of River Santa Lucia, between Myriophyllum, $\mathrm{pH}$ 6.0. In the Neotropical region this species was previously recorded from Ecuador (Koste \& Böttger 1992, in a species list).

* Testudinella ohlei Koste, 1972a (Fig. 19)

The specimens found in El pacu ( $\mathrm{pH} \mathrm{6.0)} \mathrm{are} \mathrm{slight-}$ ly smaller than those originally described by Koste (1972). This rotifer, restricted to the Neotropis, was described from Brazilian acid waters and recorded also from Ecuador (Koste \& Böttger, 1992)

* Trichocerca hollaerti De Smet, 1990 (Figs. 20 a-c)

This species resembles T. lophoesa. Both species share a well developed keel with striated area running up to the caudal end. However, they can be identified by the trophi (Segers \& Sarma 1993). T. hollaerti was described from Africa (De Smet 1990). Segers \& Sarma (1993) founded it in Brazil.

\subsection{New records from Neotropical Region: descrip- tions and notes on their distribution}

Ploesoma africana, Ptygura kostei, Testudinella brevicaudata and Trichocerca vernalis are new records. Trichocerca vernalis Hauer, 1936 (Figs. 21 a,b) is a cosmopolitan taxon (Shiel \& Koste 1992).

- Ploesoma africana Wulfert, 1965 (Figs. 22 a-d)

Ploesoma africana was described as a dimorphic species, which is appreciable principally in the lateral view. The Argentine specimens correspond to the «A» form in the description of Wulfert (1965). Wulfert's record includes figures and a description, but no measurements were provided. Variability in size was recorded, but the lorica ornamentation appears to be constant in the Argentine specimens. The possible synonymy of $P$. africana with $P$. lenticulare was suggested by Koste (1978). P. africana is distinguished from $P$. lenticulare by its occipital margin, having lateral truncate projections and by the dorsal lorica being very narrow. The specimens from Laguna Junco are different from those of $P$. lenticulare and P.truncata found in other localities of Argentina (Figs. 23, 24). Nevertheless, the variability in the genus requires a more intensive investigation, there are only few illustrated record of the species, and there are no reports on intrapopulational variability. It is suggested to retain the taxa as different species until futher studies are made.

Measurements: body length 160-250, dorsal lorica width 74-95 $\mu \mathrm{m}$.

Ecology and Distribution: a small population was found in Laguna Junco. $P$. africana was recorded only 

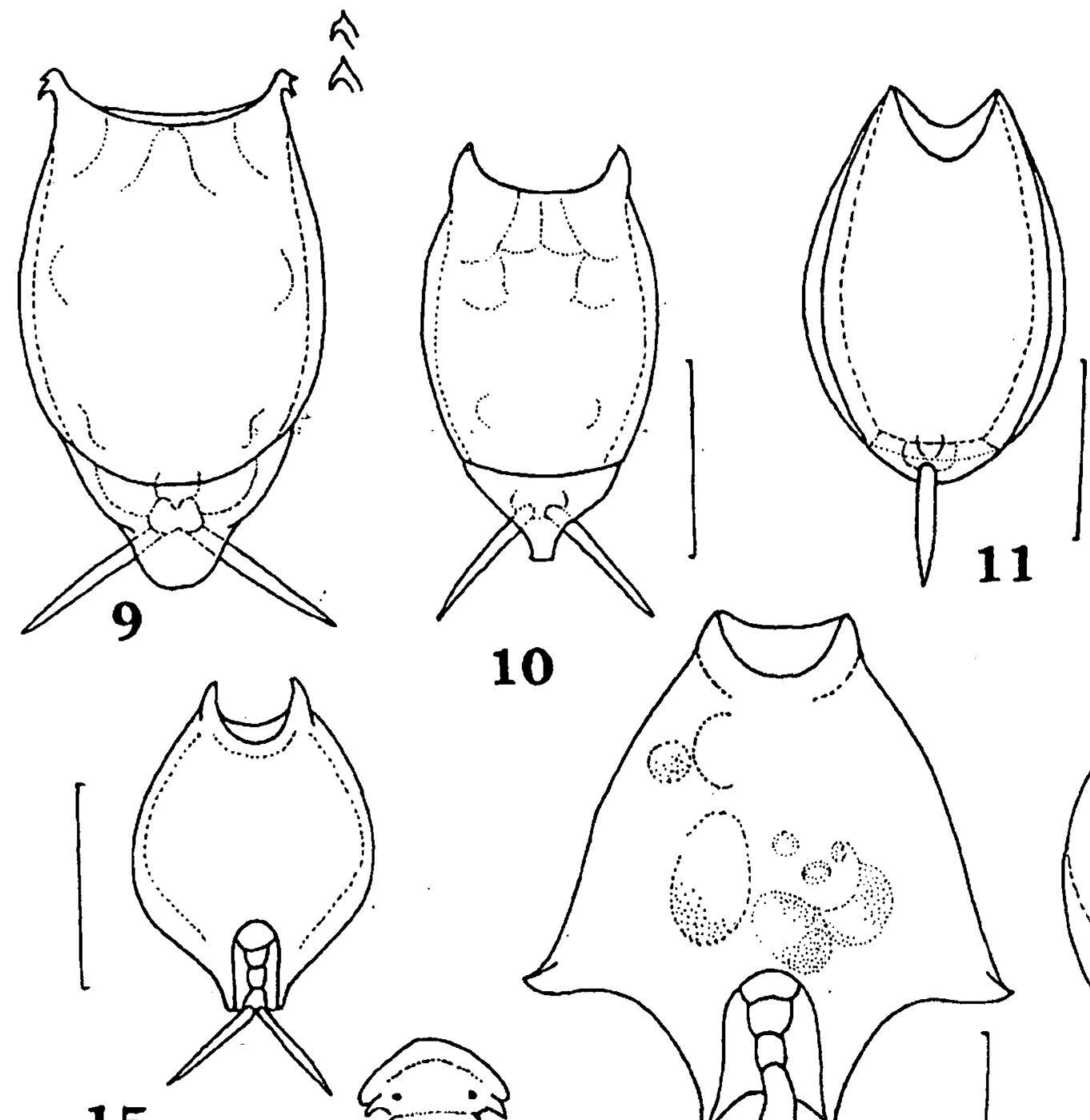

12
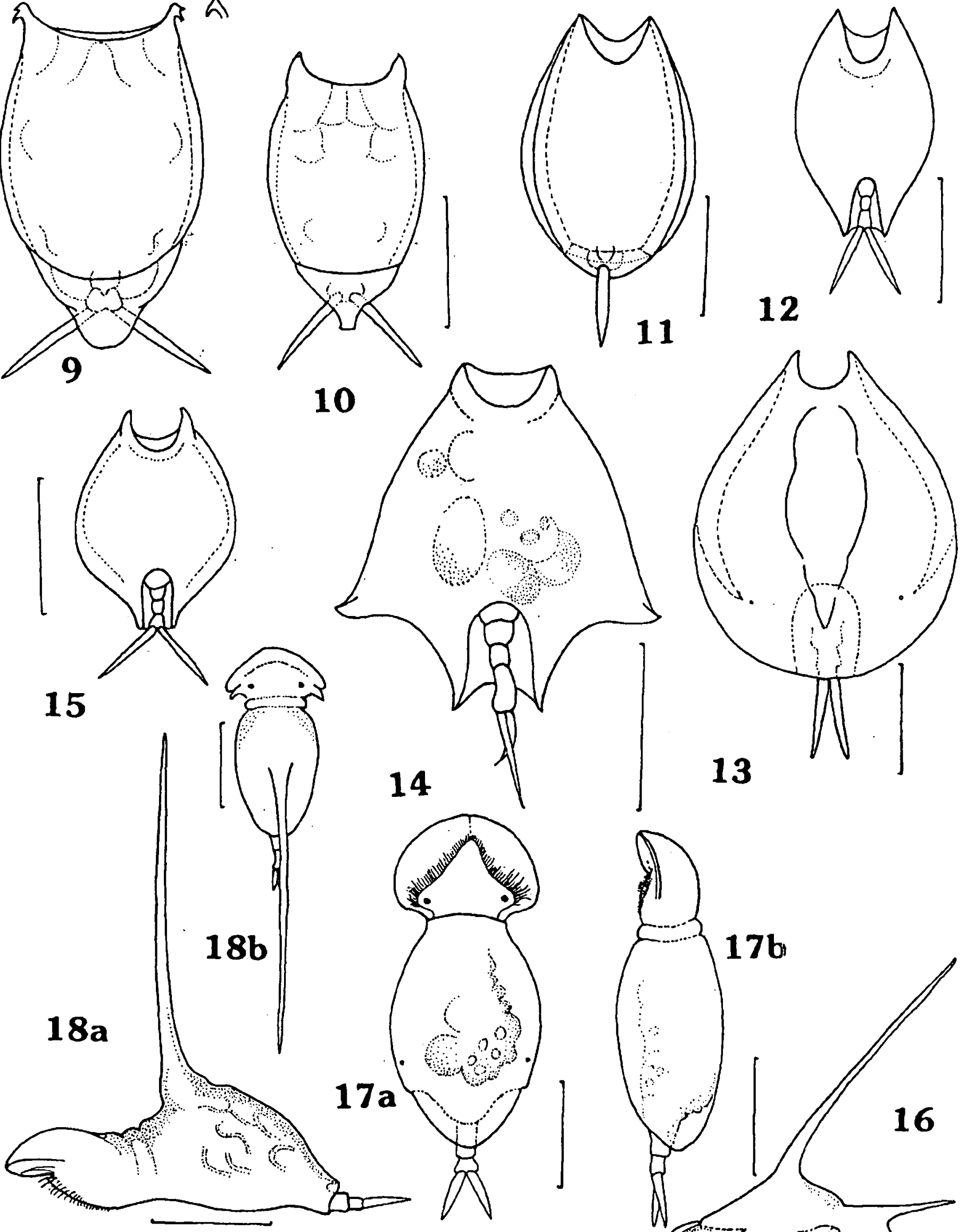

13
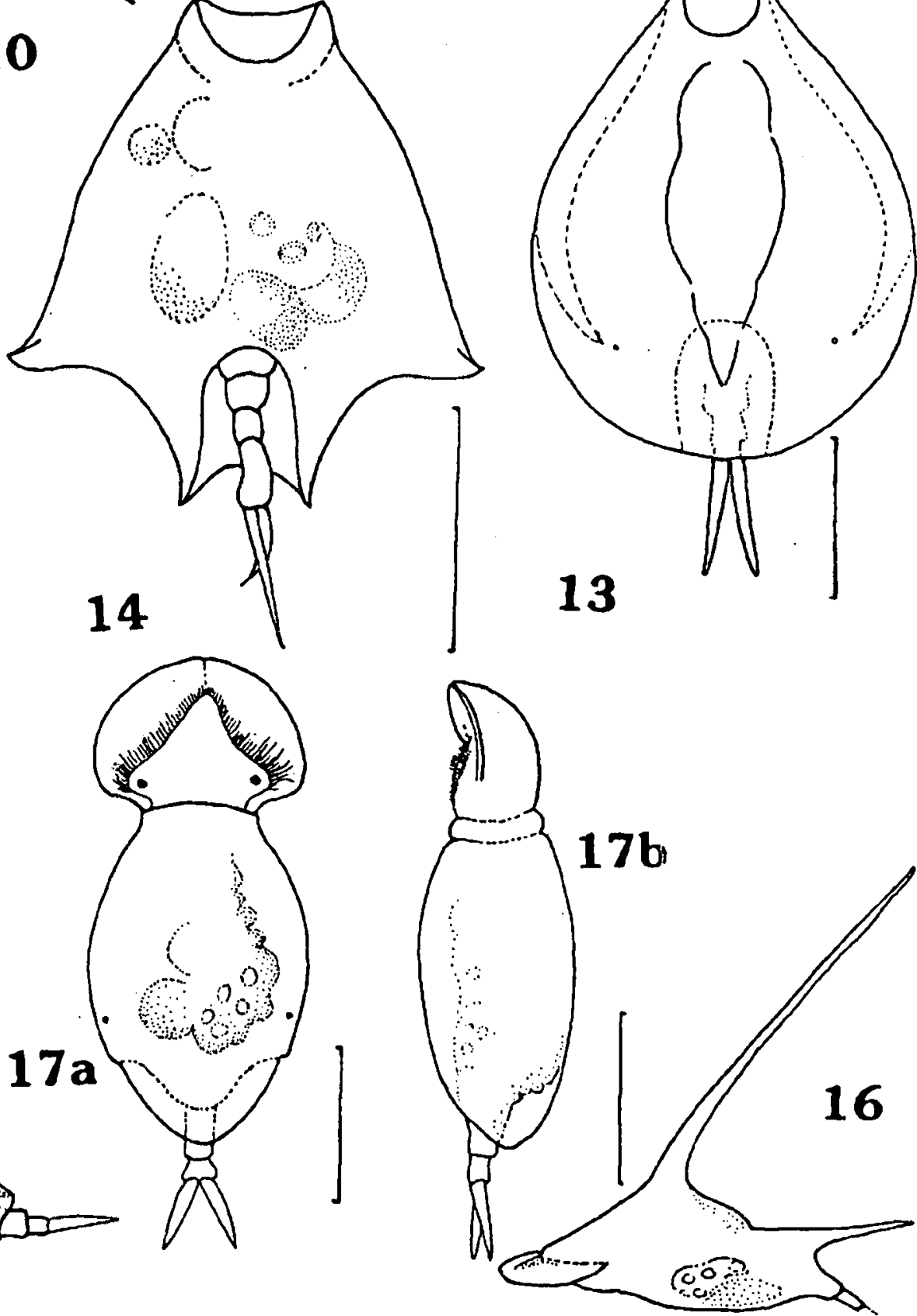

Figs. 9-18. 9. L. ludwigii f. marshi, dorsal. 10. L. ludwigii f ohioensis, dorsal. 11. L. marchantaria, ventral. 12. Lepadella biloba, ventral. 13. L. donneri, dorsal. 14. L. ehrenbergi, ventral. 15. L. elongata, ventral. 16. Squatinella bifurca, lateral. 17 a-b. S. lamellaris; a: dorsal, b: lateral. 18. a-b. S. leydigi; a: lateral, b: dorsal. Scales $50 \mu \mathrm{m}$.

Figs. 9-18. 9. L. ludwigii f. marshi, vue dorsale. 10. L. ludwigii f ohioensis, vue dorsale. 11. L. marchantaria, vue ventrale. 12. Lepadella bilo$b a$, vue ventrale. 13. L. donneri, vue dorsale. 14. L. ehrenbergi, vue ventrale. 15. L. elongata, vue ventrale. 16. Squatinella bifurca, vue latérale. 17 a-b. S. lamellaris; a: vue dorsale, b: vue latérale. 18. a-b. S. leydigi; a: vue latérale, b: vue dorsale. Echelles : $50 \mu \mathrm{m}$. 
from Africa (Wulfert, 1965). Neotropical Ploesoma include $P$. lenticulare, $P$. truncata and $P$. hudsoni.

- Ptygura kostei n.sp. (Figs. 25 a,b)

Synonyms: Ptygura elsteri f. thailandis Koste 1975, p. 50 , Figs. 3 a-c, 6,8

Ptygura elsteri f. thailandis De Smet, 1989

Ptygura elsteri f. thailandis Segers et al. 1993, p. 66.

Type locality: Mocoreta River swamp, Corrientes Province, Argentina.

Material examined: female holotype deposited in the Museo de Ciencias Naturales B.Rivadavia, B.Aires (Nr.33993 ); two female paratypes in the Instituto Nacional de Limnologia (INALI, S/6795).

\section{Diagnosis}

P. kostei is distinguished by the hooks on the dorsal side of the neck. It has four smooth robust hooks, which are slightly incurved. $P$. kostei resembles $P$. elsteri but it is easily distinguished for having four hooks almost similar en size. In $P$. elsteri, in dorsal view the median hooks are smaller and the lateral hooks have small teeth on the inner side (Figs. $26 \mathrm{a}, \mathrm{b}$ ).

\section{Description}

\section{Female}

Sessil animal, without tube, peduncle not visible. Slender, tube-shaped body with soft cuticle, long foot with a small attachment disc. Minute ventral antennae. The most important morphological characteristic of the species are four hooks on the neck, under the corona, in lateral view curved downwards. In contracted specimens the hooks are as long as $25-30 \%$ of the total length. Because of the body contraction of most of the studied specimens, the shape of the corona is not well defined and cannot be described.

Measurements: contracted body:100-110 $\mu \mathrm{m}$, median hook: $26 \mu \mathrm{m}$, lateral hook: $28 \mu \mathrm{m}$.

Male:unknown.

Distribution: Ptygura kostei is known from the type locality; few contracted individuals were found in waters of pH 7.4 in a swamp, between Salvinia and Azolla. Koste (1975) found it on Eichhornia in water with $\mathrm{pH} 7.9$ in Thailand.Besides, the species has been recorded from Africa (De Smet 1989, Segers et al. 1993b). Probably, P.kostei is a tropicopolitan species.

Etymology: this new species is dedicated to Dr. W.Koste, in honour of his contribution to the knowledge of the Southamerican rotifer fauna and for his encouragements to students and colleagues of this continent.
Comments: the species was described from Thailand by Koste (1975) as an infraspecific taxon, $P$. elsteri f. thailandis; this, and $P$. elsteri were found together in the same sample by him. Intermediate forms were not described by Koste and neither found in the Argentine material. The structure of dorsal process seems to be a valid character for the diagnosis of Ptygura species. In this genus, there are groups of species with different types of hooks or spines as $P$. furcillata, P. melicerta, $P$. múcicola, $P$. elsteri and P: linguata:

\section{- Testudinella brevicaudata Yamamoto, 1951} (Fig. 27)

The specimens found correspond with the description of Koste \& Tobias (1987): both anterior margin shape and foot aperture being situated at the posterior end of ventral lorica.

Measurements: lorica length $128 \mu \mathrm{m}$, lorica width $100 \mu \mathrm{m}$.

Ecology and distribution: T. brevicaudata was described from Japan and recorded from Africa by Koste \& Tobias (1987). It was found in Pago de los deseos, a shallow, densely vegetated pond, $\mathrm{pH}$ 7.4.

\section{Discussion}

The area dealt with in this study has a noticeable rich rotifer fauna, and a clear relationship between rotifer richness and habitat heterogeneity was observed.

Most of the recorded taxa are littoral, only $30 \%$ of them are planktonic, and all new records for Argentina or Neotropical region are littoral indeed.

There is a far higher number of species in lakes with higher development and diversity of the macrophytes (group II) than in those belonging to the groups I and III. The mean richness of these groups of habitats was 33,14 , and 15 respectively. The highest numbers of species (56 and 51) were recorded in Lake Concepción and Lake Junco, respectively, both with dense submerged and floating macrophyte growth, such as Myriophylum, Egeria, Nymphoides, Azolla and Salvinia. On the other hand, the lowest number of species (2) was found in Lake La Mula, a man-made water-body without macrophytes.

The rotifer fauna of the studied region is at all not homogenous and its faunistic affinity is relatively low. The value of the Index of Biotal Dispersity (Koch 1957) was only $10 \%$.

Many of the species are confined to a restricted number of biotopes. Only 4 species (Testudinella patina, Polyarthra vulgaris, Keratella cochlearis, Lecane bul- 


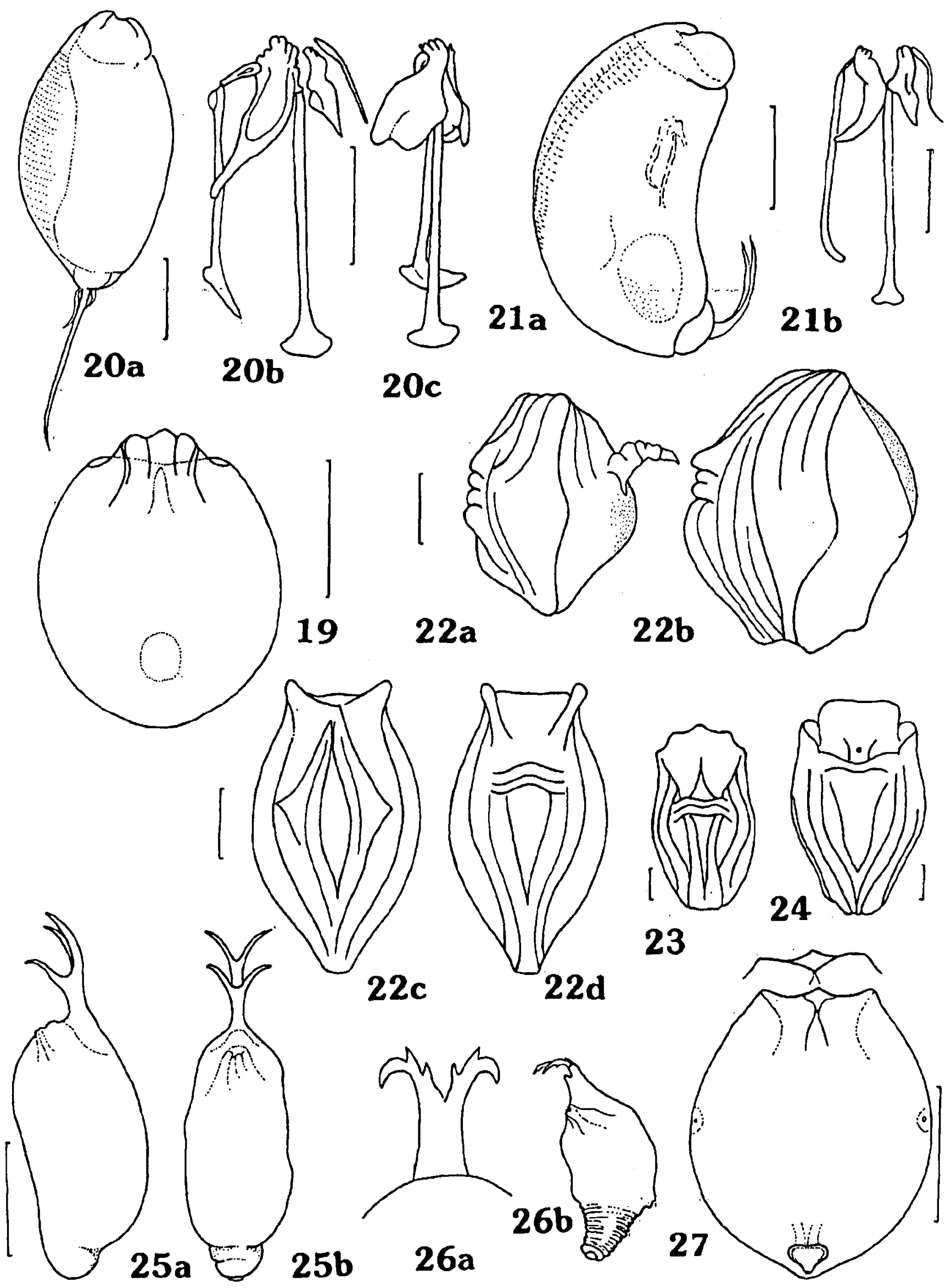

Figs. 19-27. 19. Testudinella ohlei, dorsal. 20 a-c. Trichocerca hollaerti; a: lateral, b-c: trophi. 21 a-b. T. vernalis; a: lateral, b: trophi. 22 a-d. Ploesoma africana; a-b: lateral, c: ventral; d: dorsal. 23. P. lenticulare, dorsal (Colastine Riber). 24. P. truncata, dorsal (Parana River). 25 ab. Prygura kostei, contracted; a: ventral, b: lateral. 26 a-b. P. elsteri (after Koste 1972b, 1974b); a: hooks, b: lateral; 27. Testudinella brevicaudata, ventral. Scales $50 \mu \mathrm{m}$; trophi $25 \mu \mathrm{m}$.

Figs. 19-27. 19. Testudinella ohlei, vue dorsale. 20 a-c. Trichocerca hollaerti; a: vue latérale, b-c: trophi. 21 a-b. T. vernalis; a: vue latérale, b: trophi. 22 a-d. Ploesoma africana; a-b: vues latérales, c: vue ventrale; d: vue dorsale. 23. P. lenticulare, vue dorsale (Colastine Rivière). 24. P. truncata, vue dorsale (Parana Riber). 25 a-b. Ptygura kostei, contracted; a: vue ventrale, b: vue latérale. 26 a-b. P. elsteri d'après Koste 1972b, 1974b); a: crochets, b: vue latérale; 27 . Testudinella brevicaudata, vue ventrale. Echelles : $50 \mu \mathrm{m}$; trophi $25 \mu \mathrm{m}$. 
la) of the 136 species recorded occur in $50 \%$ of the water bodies. Conversely, $85 \%$ of the species were recorded from less than $25 \%$ of the localities and 68 taxa in only one or two water bodies.

The most diverse genera were Lecane (29\%) and Trichocerca (11\%). In recent studies, Segers \& Sarma (1993) and Segers et al.(1993b) founded a similar composition in littoral-associated rotifer assemblagesin Brazil and Africa. Some species with restricted distribution to Brazil were found in Argentina as L. braziliensis, L. amazonica and L. marchantaria. Species with a tropical and subtropical distribution were recorded as Lecane aculeata, L. crepida, L. hornemanni, L. monostyla, L. papuana, L dorissa and Trichocerca hollaerti. Other species known as rare in distribution were recorded for the second time in Argentina, L.rhytida and L. halyclista.

The genus Testudinella was also well represented in vegetated lakes mainly in acid waters. Four taxa of this genus were found coexisting in a farm pond (locality 22).

The Brachionus species are mainly restricted to the tropics and subtropics, with a high number of endemics in South America (Green 1972, Dumont 1983). However the diversity of Brachionus in Corrientes was relatively low in comparison to similar latitude of Argentina (Jose de Paggi \& Koste 1988) probably because of the dominance of slightly acid waters.

Most of the 136 species of rotifer found in the studied area are cosmopolitan and tropicopolitan; 11 $(8 \%)$ of them are presently known as endemic to the Neotropical region: Brachionus dolabratus, B. havanaensis, B. zahniseri, Horaella thomassoni, Keratella americana, Lecane amazonica, L. braziliensis, L. marchantaria, L. proiecta, Lepadella donneri and Testudinella ohlei

It seems that the acidity of waters in tropical and subtropical areas does not affect negatively the richness of the rotifer fauna, on the contrary the high rotifer richness of Amazonian and Australian acid waters (Brandorff et al. 1982, Koste \& Shiel 1986) is well known. The high rotifer diversity of the slightly acid waters of Lakes Concepción and El Junco, was previously not recorded from other biotopes in Argentina. The rotifer diversity of this region is higher than that in other Argentine subtropical areas, at the same latitude (Jose de Paggi 1989). In the northwestern region of Argentina, 87 rotifer taxa were recorded from 51 localities and the highest species number by biotope was 27 . These biotopes, in arid and semi-arid climate, have alkaline waters $(\mathrm{pH} 7.5$ - 8.9) in contrast with those in Corrientes.
There is a remarkable similarity between the rotifer faunas from Corrientes and from Amazonian «black waters». Similar environmental conditions seem to have allowed the extention of some Amazonian species to the South, besides the studied region had a tropical climate between 1400- 800 years before present (Iriondo 1995). Many of the present records are the southernmost ones of many species belonging to the genera Lecane, Testudinella, Trichocerca and Lepadella. On the other hand, South America rotifer fauna have some affinities with the Africa fauna (Segers \& Sarma 1993, Segers et al. 1993) the record of P. africana contributes to this hypothesis.

This study shows the state of our knowledge: samples from a comparatively small area with 25 localities, result in 20 new rotifers for a country and 4 new records for Neotropis, besides, rare species or recorded in only one opportunity from Neotropis (L. ludwigii f. marshi, S. bifurca, S. leydigi) are found. The tropical and subtropical region of South America is dominated by rivers and associated floodplains, wetlands and shallow lakes, the largest basins of the continent: Amazonas, Orinoco and Parana are located mainly in this region. The area covered by wetlands in South Ameri$\mathrm{ca}$ is $>800.000 \mathrm{~km} 2$ (Neiff et al. 1994). Taking that into account, the extension of habitats for rotifers is huge. More intensive studies on rotifer fauna of this region are needed and could contribute for a better knowledge of the distribution patterns of the species and its biogeography at world level.

\section{Acknowledgements}

I am grateful to Prof. J.C.Paggi for the samples and his comments on the manuscript. I would like to thank two anonymous referees for their critical comments. This work was supported by CONICET grant PID 3-076000/88.

\section{References}

Brandorf G., Koste W. \& Smirnov N.N.1982. - The composition and structure of Rotiferan and Crustacean communities of the lower Rio Nhamunda, Amazonas, Brazil. Stud. Neotrop. Fauna Environ., 17: 69-121.

De Smet W.H.1989. - Contribution to the rotifer fauna of the BasZaire. 1. The rotifers from some small ponds and a river. Biol. Jb. Dodonaea, 56: 115-131.

De Smet W.H. 1990. - Contribution to the rotifer fauna of the BasZaire. 2 Species composition and seasonal abundance of rotifers in a shallow pond. Biol Jb. Dodonaea, 57: 62-77.

Dumont H.J. 1983. - Biogeography of rotifers. Hydrobiologia, 104: $19-30$.

Green J. 1972. - Latitudinal variation in associations of planktonic Rotifera. J.Zool. Lanit, 167:31-39.

Harring H.K. \& Myers F.J. 1926. - The Rotifer Fauna of Wisconsin. III A revision of the genera Lecane and Monostyla. Trans. Wisconsin Acad. Sci.,Arts and Letters, 22:315-423.

Hauer J. 1956. - Rotatorien aus Venezuela und Kolombien. Ergebnisse der deutschen Limnol. Venezuela-Expedition 1952 1: 277 314. 
Iriondo M.H. 1981. - Antiguedad del ultimo cambio climatico en el Litoral. Ecologia, 6:5-8.

Iriondo M.H. \& Krohling D.M. 1995. - El sistema eólico pampeano. Com. Mus. Prov. Cs. Naturales, 5: 1-68.

Jose de Paggi S. 1989. - Rotiferos de algunas provincias del Noroeste argentino. Rev. Hydrobiol. trop., 22: 223-238.

Jose de Paggi S. 1990. - Ecological and biogeographical remarks on the rotifer fauna of Argentina. Rev. Hydrobiol. trop., 23: 297. 311.

Jose de Paggi, S. \& Koste W. 1988. - Rotifera from Saladillo River basin (Santa Fe Province, Argentina). Hydrobiologia, 157: 13-20.

Koch L.F. 1957. — Index of biotal dispersity. Ecology, 38: 145- 148.

Koste W. 1972a. - Rotatorien aus Gewässern Amazoniens. Amazoniana 3: 258-505.

Koste W. 1972b. - Über ein sessiles Rädertier aus Amazonien, Prygura elsteri n.sp mit Bemerkungen zur Taxonomie des Artkomplexes Ptygura melicerta (Ehrenberg 1832). Int . Revue ges. Hydrobiol., 57(6): 875-882.

Koste W. 1974a. - Rotatorien aus einem Ufersee des unteren Rio Tapajos, dem Lago Paroni (Amazonien). Gewässer und Abwässer, 53/54: 43-68.

Koste W. 1974b. - Zur Kenntnis der Rotatorienfauna der «schwimmenden Wiese» einer Uferlagune in der Varzea Amazoniens, Brasilien. Amazoniana 5(1): 25-59.

Koste W. 1975. — Über den Rotatorienbestand einer Mikrobiozönose in einem tropischen aquatischen Saumbiotop, der Eichhornia crassipes Zone im Litoral des Bung-Borapet, einem Stausee in Zentralthailand. Gewässer und Abwässer, 57/58: 43-58.

Koste W. 1978. - Rotatoria. Die Rädertiere Mitteleuropas. Borntraeger, Berlin, 2 Vols: 673 p, 234 platten.

Koste W. 1986. - Über die Rotatorienfauna in Gewässern sudostlich von Concepcion, Paraguay, Sudamerika. Osnabrücker naturwiss. Mitt., 12: 129-155.

Koste W. 1988. - Über die Rotatorien einiger Stillgewasser in der Umgebung der Biologischen Station Panguana im tropischen Regenwald in Peru. Amazoniana, 10: 303-325.

Koste W. \& Bottger K. 1992. - Rotatorien aus Gewässern Ecuadors 11. Amazoniana, 12: 263-303.

Koste W., Janetzky W. \& E. Vareschi. 1993. - Zur Kenntnis der limnischen Rotatorienfauna Jamaikas (Rotatoria: Aschelminthes) Teil 1. Osnabrücker naturwiss. Mitt.,. 19: 103-149.

Koste W.\& Jose de Paggi S. 1982. - Rotifera of the Superorder Monogononta recorded from Neotropis. Gewässer und Abwässer, 68/69: 71-102.

Koste W. \& Robertson B. 1983. - Taxonomic studies on the Rotifera (Phylum Aschelminthes) from a Central Amazonian varzea lake, Lago Camaleao (Ilha de Marchantaria, Rio Solimoes, Amazonas, Brazil). Amazoniana 8: 225-254.

Koste W. \& Robertson B. 1990. - Taxonomic studies of the Rotifera from shallow waters on the island of Maraca, Roraima, Brazil. Amazoniana, 11 (2): 185-200.

Koste W. \& Shiel R.J. 1986. - New Rotifera (Aschelminthes) from Tasmania. Trans. R. Soc. S. Aust., 110(3): 93-109.

Koste W.\& Shiel R. 1990. - Rotifera from Australian inland waters V. Lecanidae (Rotifera: Monogononta). Trans. R. Soc. S. Aust., 114: 1-36.

Koste W. \& Tobias W. 1987. - Zur Rädertierfauna des Sankarani Stausees im Einzugsgebiet des Niger, Republik Mali, Westafrika (Aschelminthes, Rotatoria). Arch. Hydrobiol., 108: 499-515.
Modenutti B.E. \& M.C.Claps. 1988, - Monogononta Rotifers from plankton and periphyton of pampasic lotic environments (Argentina). Limnologica, 19: 167-175.

Neiff J.J., Iriondo M.H. \& Carignan R. 1994. - Large tropical South American wetlands. Proceedings of International Worshop on Ecology and Management of Aquatic-Terrestrial ecotones : 156165.

Pejler B. 1962. - On the taxonomy and ecology of benthic and periphytic Rotatoria.Investigations in Northern Swedish Lapland. Zool.Bidr. Uppsala, 33: 327-422.

Schmid Araya J.M. 1991. - Distributional aspects of Rotifera in Central and South Chile. Arch. Hydrobiol., 120: 481-493.

Segers H. 1993. - Rotifera of some lakes in the floodplain of the River Niger (Imo State, Nigeria). New species and other taxonomic considerations. Hydróbiologia, 250: 39-61.

Segers H. 1995. - The Lecanidae (Monogononta), In Dumont, H. (ed) Guides to the Identification of the Microinvertebrates of the Continental Waters of the World. The Hague, SPB Academic Publishing: $226 \mathrm{p}$.

Segers H. 1996. - The biogeography of littoral Lecane Rotifera. Hydrobiologia, 323:169-197.

Segers H., Ajayi A.O, Chiambeng G.Y., Chuah H.P., Del Castillo M., Directo M.G., Luzuriaga de Cruz M., Moreno L., OliveiraNeto A \& Retnaning Widyastuti. Y. 1991. - Fourteen Rotifers species new to the Belgian Fauna with nomenclatural and taxonomical remarks on some Squatinella species. Belg. J.Zool., 121: 193-201.

Segers H. \& De Meester L. 1994. - The Rotifera of Papua New Guinea, with the description of a new Scaridium Eheremberg 1830. Arch. Hydrobiol., 131: 111-125.

Segers H., Dos Santos Silva E.N. \& Oliveira Neto A.L. 1993. New and rare species of Lecane and Lepadella (Rotifera: Lecanidae: Colurellidae) from Brazil. Belg.J. Zool., 123: 113-121.

Segers H. \& Dumont H.J. 1995. - 102+ rotifer species (Rotifera : Monogonta) in Broa reservoir (SP., Brazil) on 26 August 1994, with the description of three new species. Hydrobiologia, 316: 183-197.

Segers H., Meneses L. \& Del Castillo M. 1994. - Rotifera (Monogononta) from Lake Kothia, a high altitude lake in the Bolivian Andes. Arch. Hydrobiol., 132: 227-236.

Segers H., Nwadiaro C.\& Dumont H.J. 1993. - Rotifera of some lakes in the floodplain of the River Niger (Imo State, Nigeria). II. Faunal composition and diversity. Hydrobiologia, 250: 63-71.

Segers H. \& Sarma S.S.S. 1993. - Notes on some new or little known Rotifera from Brazil. Rev. Hydrobiol. trop., 26 (3): 175185

Segers H., Sarma S.S.S., Kakkassery F.K. \& Nayar C.K.G. 1994. New records of Rotifera from India. Hydrobiologia, 287: 251258.

Shiel R.J. \& Koste W. 1992. - Rotifera from Australian inland waters. VIII Trichocercidae (Monogononta). Trans. R. Soc. S. Aust., 116: 1-27.

Thomasson K. 1963. - Araucarian lakes. Plankton studies in North Patagonia with notes on terrestrial vegetation. Acta Phytogeogr. Suec., 47: $139 \mathrm{p}$.

Thomasson K. 1971. - Amazonian algae. Mem. Inst. r. Sci.Nat. Belg., ser 2,86: 53 p.

Wulfert K. 1965. - Rädertiere aus einigen afrikanischen Gewässern. Limnologica, 3: 347-366. 